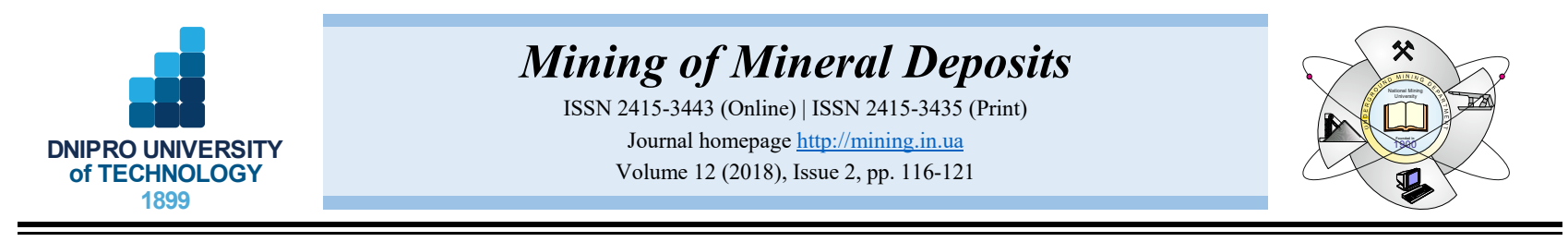

UDC 622.276.74

https://doi.org/10.15407/mining12.02.116

\title{
PRODUCTION OF HYDROCARBONS FROM WEAKLY CONSOLIDATED SANDSTONE RESERVOIRS IN THE CROATIAN PART OF THE PANNONIAN BASIN SYSTEM
}

\author{
J. Ivšinović ${ }^{1,2^{*}}$, V. Pleteš ${ }^{1}$, M. Marinić ${ }^{1}$ \\ ${ }^{I}$ INA-Industry of Oil Plc., Zagreb, Croatia \\ ${ }^{2}$ University of Zagreb, Zagreb, Croatia \\ *Corresponding author: e-mail josip.ivsinovic@ina.hr, tel. +38598311307
}

\begin{abstract}
Purpose. More efficient production of hydrocarbons from weakly consolidated sandstone reservoirs using improved method. Modification of the equipment according to the geological characteristics of the reservoir and the mode of production.

Methods. Perforation is performed with two different types of charges (DP \& BH), after that the modified gravel pack equipment is run in hole.

Findings. The combination of double perforation and the application of modified gravel pack allows for more efficient hydrocarbons production from weakly consolidated reservoir without occurrence of sand in the flow, thus extending the production life of the oil and gas field with this type of problem in production.

Originality. Application of improved method in hydrocarbon production from weakly consolidated reservoirs, which has shown improvement of production parameters.

Practical implications. The technical and economic indicators of this method show the feasibility of its application to weakly consolidated reservoirs, allowing higher production of wells, thereby increasing the profitability of the field, and thus its lifetime. It is applicable to all weakly consolidated reservoirs, with proper design of gravel pack and analysis of geological properties of reservoirs.
\end{abstract}

Keywords: weakly consolidated reservoirs, modified gravel pack, prosper analysis, economic evaluation, Pannonian basin system

\section{INTRODUCTION}

Inflow of sand into the wellbore from the weakly consolidated sediments impairs the desired oil and gas production and is a major problem for surface production system. The emergence of sand in the tubing is a serious impediment which reduces production of oil and gas while the presence of sand in the surface system poses a threat to connecting pipelines and gathering transportation system. Methods for controlling the sand inflow can be divided into: conventional and gravel pack. Gravel pack is a method of setting a barrier which prevents undesirable inflow of sand from the reservoir into the wellbore.

The choice of the preferred sand-control method depends mostly on installation costs and the degree of installation success in a particular area. Installation of gravel pack in the well causes problems, e.g. reduction of productivity index. Gravel pack represents an obstruction in the wellbore and as such affects the oil and gas production.
Factors influencing the flow of sand are: depth of reservoir, reservoir pressure, permeability, formation compaction, formation damage, reduced pressure and sand reservoir properties. When installing gravel pack, it is important to select clear fluid for performing workovers. The selected fluid must be compatible with the reservoir fluid for the sake of stabilizing the borehole walls, preventing the collapse and permanent da-mage of the formation. On weakly consolidated sandstones of field $\mathrm{C}$, wells are not able to produce sand primarily due to the surface system. That is why the problem of sand inflow must be solved by installation of modified gravel pack.

The basic problem of gravel pack is the cost of installation and lack of equipment. Hence modified version of gravel pack was created just for reservoirs of Sava Depression. With modified gravel pack, costs have been reduced and a very high level of installation is achieved. A combined perforation was first done in the well J-160 with the deep penetrating $(\mathrm{DP})$ charge and bigger hole $(\mathrm{BH})$ charge before installing gravel pack. The results are presented below.

(C) 2018. J. Ivšinović, V. Pleteš, M. Marinić. Published by the Dnipro University of Technology on behalf of Mining of Mineral Deposits.

This is an Open Access article distributed under the terms of the Creative Commons Attribution License (http://creativecommons.org/licenses/by/4.0/),

which permits unrestricted reuse, distribution, and reproduction in any medium, provided the original work is properly cited. 


\section{THE GEOLOGICAL DESCRIPTION OF THE AREA UNDER STUDY}

The oil and gas field $\mathrm{C}$ investigated in this paper is located in the Croatian part of the Pannonian Basin System in the western part of Sava Depression (Fig. 1).

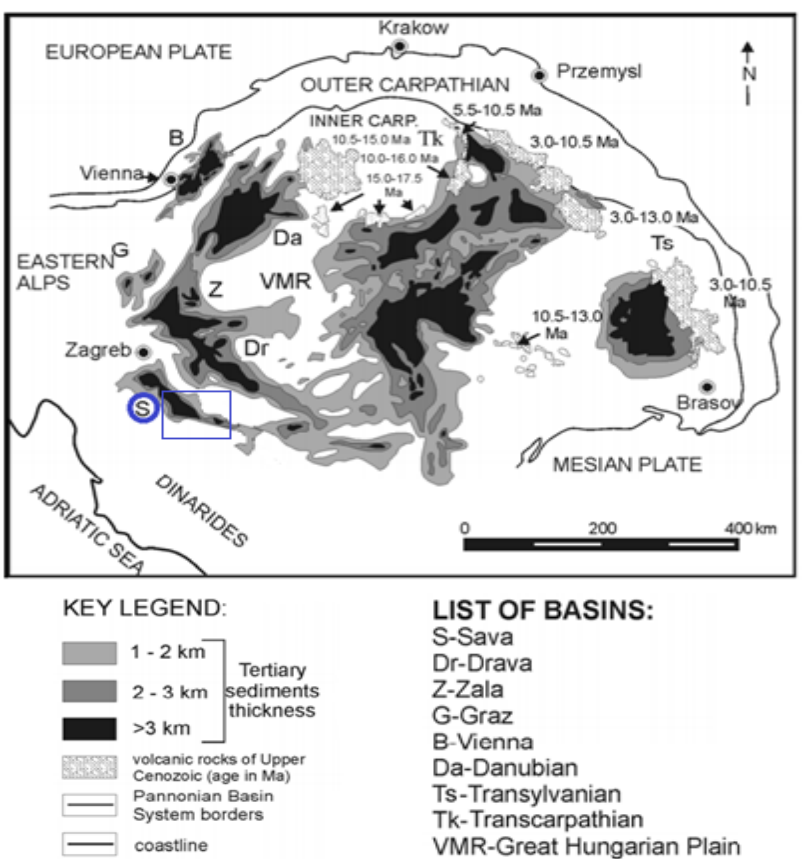

Figure 1. Location of the oil and gas field C (blue) within the Pannonian Basin System (modified after Royden, 1988; Malvić, 2003)

The geographic location of the oil and gas field $\mathrm{C}$ is about $90 \mathrm{~km}$ south-east of Zagreb. The lowest part of the terrain represents a valley in the southern part of the field at the height of $120 \mathrm{~m}$, while the highest point in the northeastern part of the field is $231 \mathrm{~m}$, which accounts for height difference of $111 \mathrm{~m}$. The relief is characterized by steep slopes. According to the reservoir classification (Brod, 1945; Velić, 2007), the reservoirs of oil and gas C belong to a group of layered, folded reservoirs, constrained by the tectonic screen. Reservoirs on field $\mathrm{C}$ are formed from Upper Miocene and Lower Pliocene deposits. The reservoir " $\mathrm{N}$ " of field $\mathrm{C}$ is made of gray and grayish sand and weakly consolidated sandstone covered with gray soft clay and sandy marl. The average porosity of reservoir " $N$ " is $27 \%$, with a sandstone content of more than $70 \%$, while the remaining part is silt. The average mineral $\mathrm{CaCO}_{3}$ content in reservoir sediment is more than $25 \%$. The previous data refer to the typical Lower Pontian sandstone of the Sava depression, with two important values that indicate both the genesis (Malvić, 2012; Malvić, 2016) of sandstone and its reservoir properties. The first is a large proportion of silt, as this sandstone is classified as silty sandstone. Secondly, the large part of the calcite particles inside the matrix, which proves that the material originates from Eastern Alps (Malvić, 2012; Malvić, 2016). But it also makes the main cementation material in such sandstones, which can result in the formation of porosity via dissolution. Geological correlation section between wells J-129 - J-160 for the studied reservoir " $\mathrm{N}$ " is shown in Figure 2.

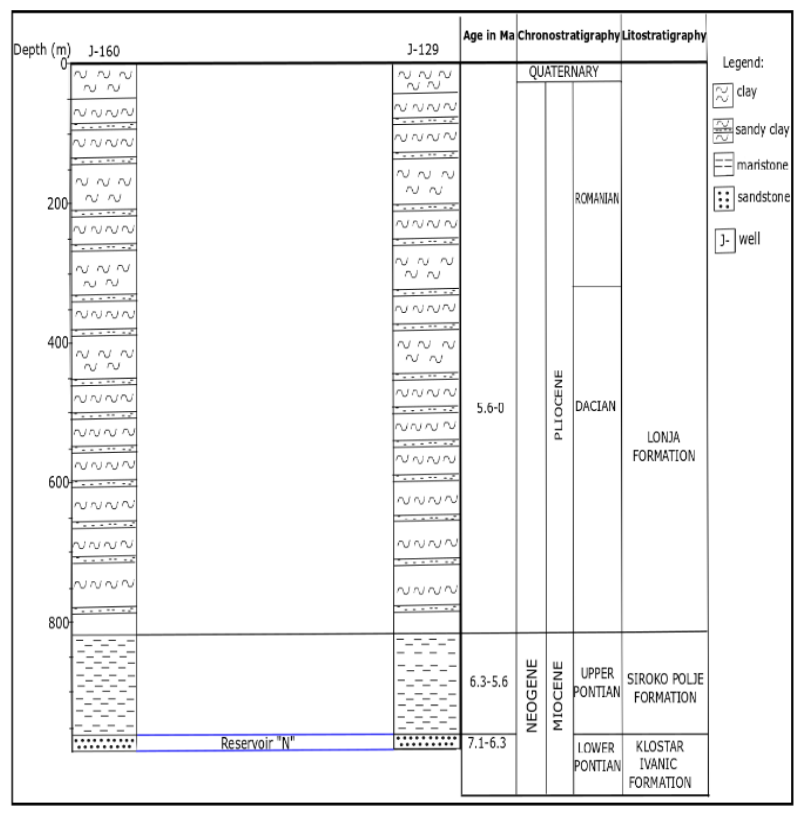

Figure 2. Geological correlation section between wells $J-129$ - J-160 for the studied reservoir " $N$ "

The thickness of the reservoirs is similar (ca. $20 \mathrm{~m}$ ) in the observed wells. Between the wells, there is no significant folding or faulting that is essential for producing hydrocarbons from this reservoir. Because of the relatively low depth $(<1000 \mathrm{~m})$, the compaction of the reservoir is weak, which puts hydrocarbon production from these deposits at high risk of solid particles penetration into the production fluid.

\section{INSTALLATION OF MODIFIED GRAVEL PACK (MGP)}

Before installing the modified gravel pack (MGP), the borehole needs to be cleaned with a scraper. After cleaning, the DDN/GR/CCL diagrams are recorded and the column is calibrated. The TCP perforator on the working line of the tubing is used for perforating intervals. Perforation is repeated with two different types of charging: DP and BH (Fig. 3). (a)

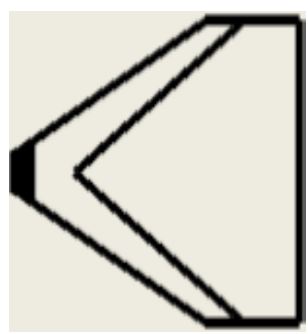

(b)

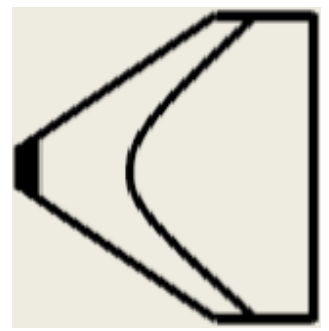

Figure 3. Types of charging: (a) DP charge; (b) BH charge (Perforating Basics..., 2009)

DP charge is characterized by deep penetration, but smaller entrance hole in the casing wall (produces a 0.55 " hole diameter and 17.3 " of penetration), while $\mathrm{BH}$ charge creates a bigger hole, but much less penetration in the rock (produces a 1" diameter entrance hole which is 8.8 " long) (Perforating Basics..., 2009). In this way perforation with two types of filling was first performed 
on the weakly consolidated sandstone reservoirs of field $\mathrm{C}$ in the $\mathrm{J}-160$ well. The size of the injected propane is $20 / 40$ mesh. It manages to prevent the sand from entering the borehole, though silt-sized particles do not do the job. Particles of silt in the flow can be separated in the surface system of the field $\mathrm{C}$.

Before activating TCP perforators, it is necessary to determine the desired depression by clipping. The working string on which MGP is placed needs to be washed with acid (type PT-15). Washing is done in two stages:

1) indirect washing with acid (1 volume of tubing) + + formation water (1 volume of casing);

2 ) direct circulation with formation water (2 volumes of casing), afterwards the acid is neutralized in the neutralization tank.

If necessary, filling tier material is washed down to the bottom and twice checked. After washing with acid, bent sub is run in hole and further checked down to the hole depth. When required, it is washed down to the bottom and possibly twice checked via filling borehole from reservoir materials. The packer is run in hole directly above the perforation, and pre-pack operation begins. The injectivity test was performed by injecting the fluid that is most compatible with the reservoir material (in this case it was diesel) in combination with the sand. If the pre-pack succeeds (injectivity test passed), preparatory work is performed prior to MGP run in hole. Preparatory work refers to rescrubbing the well with a bent sub and junk mill. The MGP run in hole equipment is shown in Figure 4.

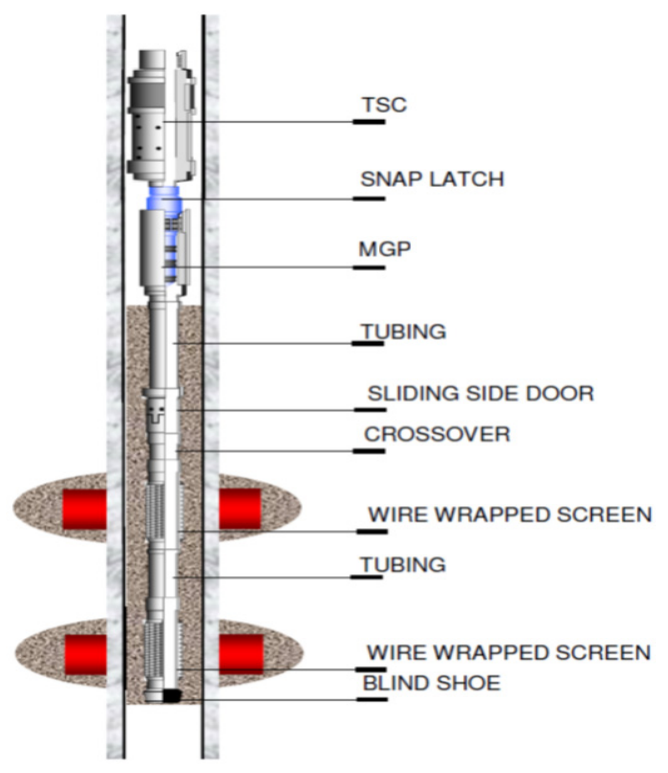

Figure 4. MGP underground equipment

Run in hole MGP equipment was followed by the injection of sand and diesel in the proportion of a given calculation. The combination of diesel and sand is injected into reservoir at a certain pressure and capacity, and is pressed with treated filtered water. After injection, several hydraulic checkups are required for 24 hours to determine sand precipitation. The installed MPG equipment disconnects the MGP connectors and is removed from the borehole. TSC sealing head is run in hole and exa-mines its imperviousness. The production equipment is run in hole and the well is put in production.

\section{PROSPER ANALYSIS}

PROSPER is a well performance, design and optimization program which is part of the Integrated Production Modelling Toolkit (IPM). Prosper (Petroleum Experts (Petex), license: INA d.d.) is designed to allow the building of reliable and consistent well models, with the ability to address each aspect of well bore modelling; PVT, Vertical Lift Performance (VLP) and Inflow Performance Relationship (IPR) (Okotie, Ikporo, \& Ovuem, 2015). Prosper provides unique matching features, which tune with PVT, multiphase flow correlations and IPR to match measured field data, allowing a consistent well model to be built prior to future use. The first step in the calculations in PROSPER is to define the system and wells, and the presence of fluid in the reservoir (Koščak Kolin, Korenjak, \& Čikeš, 2009). The required inputs for this type of model are: reservoir permeability, formation thickness, drainage area and wellbore radius. Productivity index (PI) is one of the important characteristics of a well's inflow performance which depends on the reservoir and fluid properties (Okoro \& Ossia, 2015). IPR and VLP curves for the well J-160 equipped with modified gravel pack is shown in Figure 5.

This well is producing oil from reservoir N. Model for IPR curve is Darcy. A single flowing bottom hole pressure and surface test rate is used to calculate the IPR below the bubble point. From this IPR the rate and bubble point pressure are used to evaluate the PI for the straight-line part of the inflow above the bubble point. PI for the well J-160 is $0.8621 \mathrm{sm}^{3} /$ day $/$ bar, and absolute open flow (AOF) is $37.18 \mathrm{~m}^{3} /$ day (Fig. 5). Average value of PI for wells equipped with modified gravel pack in reservoir $\mathrm{N}$ is $0.4475 \mathrm{sm}^{3} /$ day/bar, AOF is $22.04 \mathrm{sm}^{3} /$ day and flowing bottom hole pressure (FBHP) is 40.58 bar. Sucker rod pump pressure estimation data is shown in Table 1.

\begin{tabular}{lccc}
\multicolumn{4}{c}{ Table 1. Sucker rod pump pressure estimation data } \\
\hline Oil gravity, $\mathrm{kg} / \mathrm{m}^{3}$ & 895.57 & $\begin{array}{c}\text { Gas gravity } \\
\text { (sp. Gravity) }\end{array}$ & 0.81 \\
\hline Pump depth, $\mathrm{m}$ & 845.32 & Water cut, \% & 10.50 \\
\hline $\begin{array}{l}\text { Fluid level } \\
\text { producing, } \mathrm{m}\end{array}$ & 461.00 & $\begin{array}{c}\text { Casing producing, } \\
\text { BARg }\end{array}$ & 18.80 \\
\hline $\begin{array}{l}\text { MD point perfo- } \\
\text { ration depth, } \mathrm{m}\end{array}$ & 972.00 & $\begin{array}{c}\text { Liquid production } \\
\text { rate, } \mathrm{sm}^{3} / \mathrm{day}\end{array}$ & 16.68 \\
\hline
\end{tabular}

Producing intervals are at depths between 972 and $1005 \mathrm{~m}$. To calculate FBHP, it is necessary to have the following data: producing fluid level and casing pressure. In this case, fluid level is $461 \mathrm{~m}$ and casing pressure is 18 bar (Table 1 ). The calculated FBHP is 48.12 bar. The difference between flowing bottom hole pressure in the well without gravel pack and in the well with gravel pack is about 20 bars. Production of the well after completion with gravel pack is higher than before gravel pack: $Q_{1}=16.7 \mathrm{~m}^{3} /$ day, $Q_{\mathrm{o}}=14.95 \mathrm{~m}^{3} /$ day, $Q_{\mathrm{g}}=1050 \mathrm{~m}^{3} /$ day, $\mathrm{WC}=10.5 \%$, and $\mathrm{GOR}=70$.

\section{ECONOMIC EVALUATION}

Input data for economic analysis are: price of oil and gas (BP Annual Report..., 2017), costs of Artificial Lift Systems (Tennessen, 2002), costs of separation (Ivšinović, 2018) and injection (Ivšinović, 2017) of formation water, investment costs (capital workovers, well measurements etc.), and other costs (miners' wages etc.). 


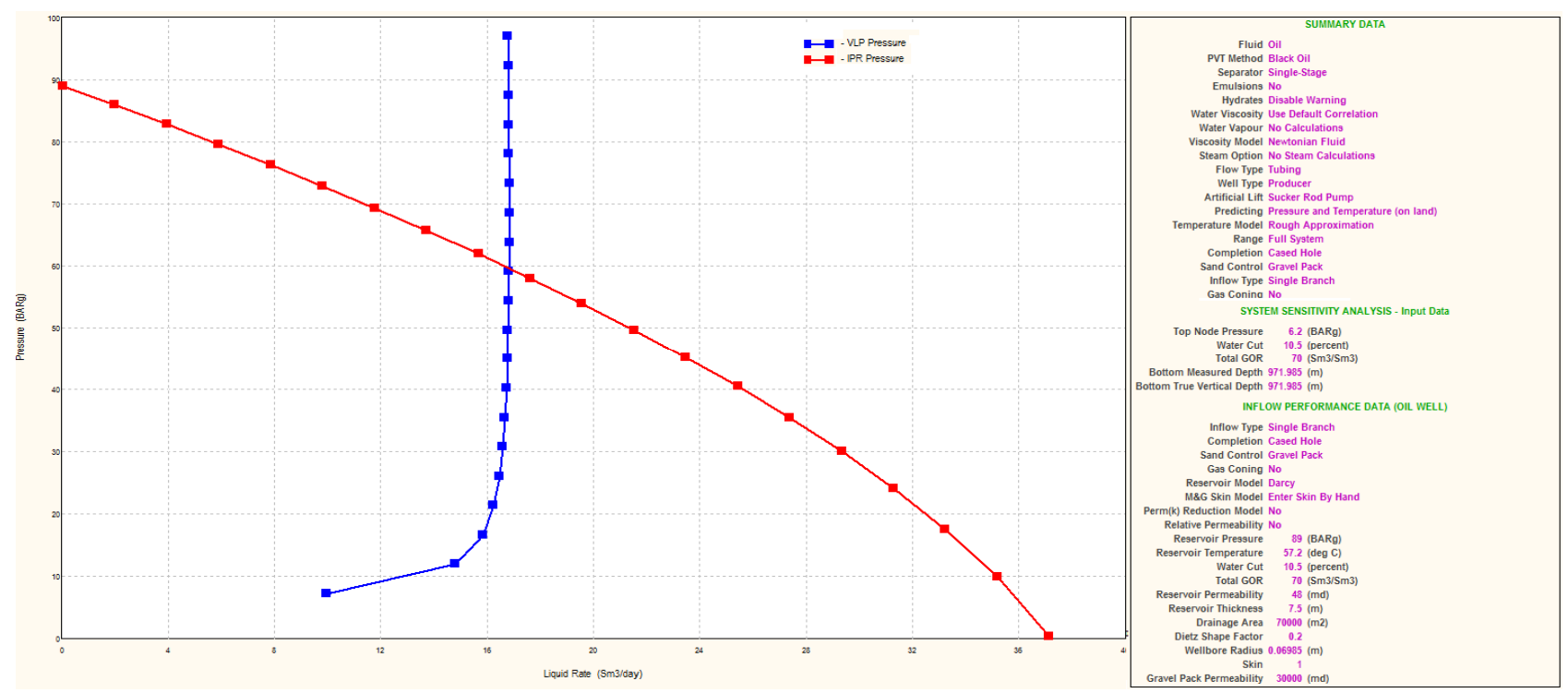

Figure 5. IPR and VLP curves for well J-160

The input quantities of hydrocarbons in the calculation are taken from the PROSPER analysis (see the previous chapter). The realized economic flow for well $\mathrm{J}-160$ is shown below (Fig. 6).

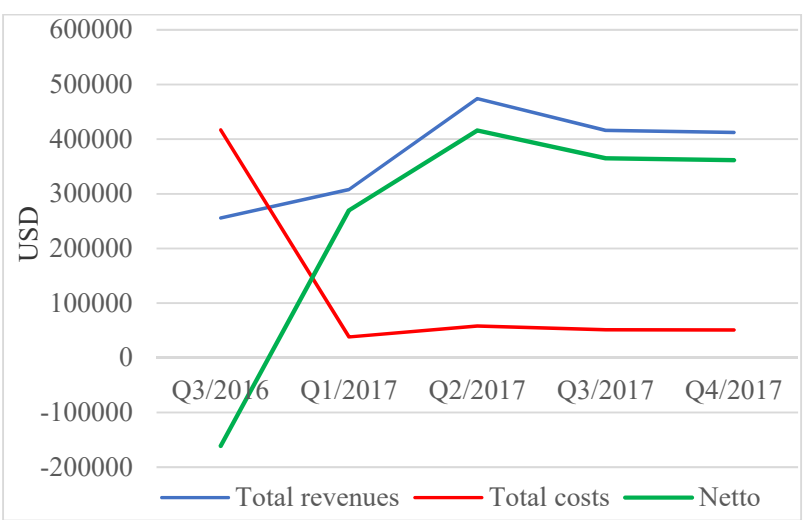

Figure 6. Realized economic flow for well J-160

At the end of the fourth quarter of 2016, the well $\mathrm{J}-160$ paid off the costs of capital investment. The net present value of USD 862000 was achieved, with a discount rate of $10 \%$. Internal Rate of Return (IRR) for this well is 1.93 , with a discount rate of $10 \%$. The main economic indicators in this case have turned positive and highly profitable in short time, which justifies investments into this type of well equipment.

\section{CONCLUSIONS}

The combination of double perforation and the application of modified gravel pack allows for more efficient production from weakly consolidated reservoir without the occurrence of sand in the flow, thus extending the production life of the field $\mathrm{C}$.

PI for the well $\mathrm{J}-160$ is $0.8621 \mathrm{sm}^{3} /$ day/bar, and AOF is $37.18 \mathrm{~m}^{3} /$ day, which is significantly higher than indicators of the previously applied methods on reservoir $\mathrm{N}$.
In the case of well $\mathrm{J}-160$, return on investment took less than four months, with net present value of USD 862000 , and internal rate of return 1.93 .

The technical and economic indicators discussed in this paper prove the feasibility of applying this method to weakly consolidated reservoirs, allowing for higher production of wells, thereby increasing the profitability of the field, and consequently the field lifetime.

\section{ACKNOWLEDGEMENTS}

The author's thanks company INA d.d. for used data and program PROSPER 14.0.

\section{REFERENCES}

BP Annual Report and Form 20-F 2016. (2017). Annual Report and Accounts. London, United Kingdom: British Petroleum.

Brod, I.O. (1945). Geological Terminology in Classification of Oil and Gas Accumulation. AAPG Bulletin, (29), 1738-1755. https://doi.org/10.1306/3d9337b2-16b1-11d7-8645000102c1865d

Ivšinović, J. (2017). The Analysis of Water Injection Systems in Sandstone Hydrocarbon Reservoirs, Case Study from the Western Part of the Sava Depression. Rudarsko-GeološkoNaftni Zbornik, 32(1), 17-24.

https://doi.org/10.17794/rgn2017.1.3

Ivšinović, J. (2018). The Cost Analysis of the Separation of Produced Formation Water from the Hydrocarbon Reservoir Using the Example of the Upper Miocene Sandstone Deposits of the Sava Depression. Rudarsko-Geološko-Naftni Zbornik, 33(1), 35-43. https://doi.org/10.17794/rgn.2018.1.5

Koščak Kolin, S., Korenjak, Z., \& Čikeš, M. (2009). Production System Modeling of the Gas Lifted Well by Means of the Program Prosper. Rudarsko-Geološko-Naftni Zbornik, 2l(1), 73-81.

Malvić, T. (2003). Oil-Geological Relations and Probability of Discovering New Hydrocarbon Reserves in the Bjelovar Sag. PhD. Zagreb, Croatia: University of Zagreb.

Malvić, T. (2012). Review of Miocene Shallow Marine and Lacustrine Depositional Environments in Northern Croatia. Geological Quarterly, 56(3), 493-504. https://doi.org/10.7306/gq.1035 
Malvić, T. (2016). Regional Turbidites and Turbiditic Environments Developed during Neogene and Quaternary in Croatia. Materials and Geoenvironment, 63(1), 39-54. https://doi.org/10.1515/rmzmag-2016-0004

Okoro, E.S., \& Ossia, C.V. (2015). Production Optimisation in the Niger Delta Basin by Continuous Gas Lift - A Case Study of Iduo-Well-A06. International Journal of Scientific \& Engineering Research, 6(10), 614-622.

Okotie, S., Ikporo, B., \& Ovuem, A. (2015). Gas Lift Technique a Tool to Production Optimization. International Journal of Oil, Gas and Coal Engineering, 3(3), 41-46. https://doi.org/10.11648/j.ogce.20150303.12
Perforating Basics. How the Perforating Processes Work. (2009). Retrieved from http://gekengineering.com/ Downloads/Free Downloads/Perforating Basics.pdf

Royden, L.H. (1988). Late Cenozoic Tectonics of the Pannonian Basin System. American Association of Petroleum Geologists Memoir, (45), 27-48.

Tennessen, R. (2002). A Comparison of the Energy Efficiency of Various Types of Artificial Lift Systems. Oil \& Gas Automation Solutions, (2), 1-4.

Velić, J. (2007). Geology of Oil and Gas. Zagreb, Croatia: University of Zagreb.

\section{ОТРИМАННЯ ВУГЛЕВОДНІВ ЗІ СЛАБОЗЦЕМЕНТОВАНИХ ПІЩАНИХ КОЛЕКТОРІВ У ХОРВАТСЬКІЙ ЧАСТИНІ ПАННОНСЬКОГО БАСЕЙНУ}

Й. Івшіновіч, В. Плетеш, М. Марініч

Мета. Удосконалення технології видобутку вуглеводнів з урахуванням геологічних характеристик колекторів на основі модернізації обладнання гравійного набивання для підвищення ефективності роботи експлуатаційних свердловин.

Методика. Для досягнення поставленої мети досліджувалися дані геологічної розвідки нафтогазового поля “C” між свердловинами J-129 і J-160. Для цих умов у свердловині J-160 була вперше виконана перфорація з двома типами заповнення у зцементованих піщаних колекторах нафтогазового поля. Для моделювання роботи свердловини використовувався програмний комплекс PROSPER (Prosper Petroleum Experts (Petex), license: INA d.d.). Обгрунтування доцільності впровадження обладнання проводилося шляхом техніко-економічної оцінки.

Результати. Розроблено комбіновану технологію перфорування свердловин із модернізованим гравійним набиванням у слабозцементованих породах. Виконано моделювання процесу роботи експлуатаційної свердловини з модернізованим гравійним набиванням в програмному пакеті PROSPER для заданих умов та визначено найважливіші технологічні параметри: індекс продуктивності, напірну характеристику, абсолютний дебіт свердловини, газовий вміст нафти та ін. Проведена економічна оцінка запропонованої технології, яка показала позитивні результати та високоприбутковість застосовуваного типу обладнання, що виправдовує доцільність вкладення інвестицій для запобігання піскування свердловин.

Наукова новизна. Полягає у застосуванні вдосконаленої технології отримання вуглеводнів зі слабозцементованих порід, що відрізняється від відомих більш ефективними технологічними показниками виробництва.

Практична значимість. Пропонована технологія за технічними й економічними аспектами $\epsilon$ найбільш прийнятним способом видобутку вуглеводнів зі слабозцементованих піщаних колекторів, що сприяє підвищенню продуктивності свердловин, збільшенню рентабельності розробки родовища та терміну його експлуатації. Дана технологія може застосовуватися до всіх родовищ зі слабозцементованою структурою порід при правильній конструкції гравійної набивання.

Ключові слова: слабозиементовані піщані колектори, модернізована гравійна набивка, PROSPER аналіз, економічна оиінка, Паннонський басейн

\section{ПОЛУЧЕНИЕ УГЛЕВОДОРОДОВ ИЗ СЛАБОСЦЕМЕНТИРОВАННЫХ ПЕСЧАНЫХ КОЛЛЕКТОРОВ В ХОРВАТСКОЙ ЧАСТИ ПАННОНСКОГО БАССЕЙНА}

\section{И. Ившинович, В. Плетеш, М. Маринич}

Цель. Совершенствование технологии добычи углеводородов с учетом геологических характеристик коллекторов на основе модернизации оборудования гравийной набивки для повышения эффективности работы эксплуатационных скважин.

Методика. Для достижения поставленной цели исследовались данные геологической разведки нефтегазового поля "C" между скважинами J-129 и J-160. Для этих условий в скважине J-160 была впервые выполнена перфорация с двумя типами заполнения в слабосцементированных песчаных коллекторах нефтегазового поля. Для моделирования работы скважины использовался программный комплекс PROSPER (Prosper Petroleum Experts (Petex), license: INA d.d.) Обоснование целесообразности внедрения усовершенствованного оборудования проводилось путем технико-экономической оценки.

Результаты. Разработана комбинированная технология перфорирования скважин с модернизированной гравийной набивкой в слабосцементированных породах. Выполнено моделирование процесса работы эксплуатационной скважины с модернизированной гравийной набивкой в программном пакете PROSPER для заданных условий и определены важнейшие технологические параметры: индекс производительности, напорная характеристика, абсолютный дебит скважины, газосодержание нефти и др. Проведена экономическая оценка предлагаемой технологии, которая показала положительные результаты и высокодоходность применяемого типа оборудования, что оправдывает целесообразность вложения инвестиций для предотвращения пескования скважин. 
Научная новизна. Заключается в применении улучшенной технологии получения углеводородов из слабосцементированных пород, отличающаяся от известных более эффективными технологическими показателями производства.

Практическая значимость. Предлагаемая технология по техническим и экономическим аспектам является наиболее приемлемым способом разработки залежей углеводородов в слабосцементированных песчаных коллекторах, что способствует повышению производительности скважин, увеличению рентабельности разработки месторождения и термина его эксплуатации. Данная технология может применяться ко всем месторождениям со слабосцементированной структурой пород при правильной конструкции гравийной набивки.

Ключевые слова: слабосиементированные песчаные коллекторы, модернизированная гравийная набивка, PROSPER анализ, экономическая оченка, Паннонский бассейн

\section{ARTICLE INFO}

Received: 7 February 2018

Accepted: 18 May 2017

Available online: 30 May 2017

\section{ABOUT AUTHORS}

Josip Ivšinović, Candidate for Doctor of Philosophy, Project Manager \& Oil Well Technology Engineer of the INA-Industry of Oil Plc., 10 V. Holjevca Ave., 10000, Zagreb, Croatia. E-mail: josip.ivsinovic@ina.hr

Vjekoslav Pleteš, Graduate in Petroleum Engineering, Oil Well Technology Engineer of the INA-Industry of Oil Plc., 10 V. Holjevca Ave., 10000, Zagreb, Croatia. E-mail: vjekoslav.pletes@ina.hr

Maja Marinić, Graduate in Petroleum Engineering, Oil Well Technology Engineer of the INA-Industry of Oil Plc., 10 V. Holjevca Ave., 10000, Zagreb, Croatia. E-mail: maja.marinic@ina.hr 